\title{
Some possible boundary-stratotypes for the base of the Cenomanian and Turonian Stages
}

\author{
JAKE MICHAEL HANCOCK
}

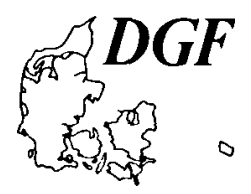

\begin{abstract}
Hancock, J. M.: Some possible boundary-stratotypes for the base of the Cenomanian and Turonian Stages. Bull. geol. Soc. Denmark vol. 33, pp. 123-128, Copenhagen, September, 11th, 1984. https://doi.org/10.37570/bgsd-1984-33-10

Historical definitions of stages are inadequate for the standards of precision in stratigraphy now required. The base of the Cenomanian is best defined by the base of the Zone of Hypoturrilites schneegansi with a boundary-stratotype north of Djebel Hameima in Tunisia. The Lower Cenomanian Graysonites fauna is Tethyan and probably failed to migrate to boreal regions. The base of the Turonian is best defined by the appearance of the main development of the inoceramid Mytiloides as represented by $M$. opalensis Kauffman non Böse. This coincides with the base of the ammonite Zone of Pseudaspidoceras flexuosum. Possible localities for the boundary-stratotype are in south-west Texas; the most suitable is probably in Calvert Canyon.
\end{abstract}

J. M. Hancock, Department of Geology, King's College. Strand, London WC2R 2LS, U.K. March 28th, 1984.

It is a common human desire for standards and units to be left unchanged. Geologists have this craving as much as all human beings. No scientific dispute ever makes them so angry as when someone proposes that a familiar name should be deleted or have its meaning changed.

In the definition of stages there have been three approaches to achieve stability. The first is to use historical definitions, and, by analogy with zoological nomenclature, apply a rigid law of priority. The second is to use stratotypes, or, in a more refined form, boundary stratotypes which should provide a standard to which stratigraphers can refer, rather like the old platinum rod standard for the international metre. It is a third method that has more generally been used in practice: the appearance of some particular faunal (or floral) assemblage, sometimes the appearance of a single species. Combinations of two, or all three of these methods, have also been tried. Definitions based on the appearance of a particular assemblage have sometimes been justified by an appeal to historical definition or the sequence in a stratotype.

\section{Historical definitions}

Historical definitions have the attraction that if they worked there would be an automatic sta- bility; we should be saved the trouble of having to ever make any new decisions; arguments for rival definitions could be settled by reference to the historical authority. But they fail on the standards of precision now required.

The limitations of historical definition are well illustrated by the base of the Turonian. D'Orbigny himself changed his definition of Turonian several times from its introduction in 1842 to his most complete discussion in 1852 (Sornay 1957). It is notable that he did not limit himself to one phylum and his emphasis was on rudists. Later authors have usually concentrated on the ammonites. Of those quoted by d'Orbigny, two species are synonyms; the two left would now be named Lewesiceras peramplum and Collignoniceras woollgari. Whilst undoubtedly Turonian, their ranges define neither the bottom nor the top of the stage as used by anyone this century.

Wright \& Kennedy (1981) have made a most careful analysis of this problem. They argue, correctly, that d'Orbigny's faunal lists show the Metoicoceras geslinianum assemblage Zone to be Cenomanian, and the Mammites nodosoides assemblage Zone, which contains $L$. peramplum, to be Turonian. Between these two zones they recognised two others: Neocardioceras juddii below, Watinoceras coloradoense above. On the basis that d'Orbigny considered the brachiopod 
Gemmarcula carantonensis to be Cenomanian, and that this species occurs alongside $N$. juddii in the Sarthe, Wright \& Kennedy argue, on admittedly thin evidence, that for d'Orbigny the stage boundary lay above this level, i.e. the juddii Zone is Cenomanian. But d'Orbigny (1852, p. 662) listed three species of brachiopods as being characteristic of the Turonian; in modern terms these are: Cyclothyris difformis (Lower to Middle Cenomanian), Orbirhynchia cuvieri (probably Zone of Mammites nodosoides) and Concinnithyris obesa (Middle to Upper Cenomanian, ? + Turonian; Keith Holdaway, pers. comm.). It is really a form of special pleading for Wright and Kennedy to pick out $G$. carantonensis from the brachiopods that d'Orbigny names. In fact one can play this sort of juggling game for years; he only regarded $M$. geslinianum as Cenomanian because he thought it came from Lamnay, near Vibraye - a Cenomanian locality. If he had known that it came from Saumur, he would probably have called it Turonian. When one considers that Cobban (this volume) has now recognised five zones between the geslinianum and nodosoides Zones in New Mexico, the inadequacy of historical definition becomes even more obvious.

\section{Proposals for the future}

At present each geologist has been defining stages from the succession of whichever biological group he is familiar with, or which he respects, commonly ammonites or foraminifera. During this symposium in Copenhagen there has been an amicable consensus on what is now needed (Birkelund et al. this volume). An accord should be sought on how to define the base of each stage, preferably on the first appearance of a new genus or new family of genera. The taxon (or taxa) to be chosen needs to be widespread, reasonably common, and for preference, identifiable by the non-specialist. The taxon used to define the base of a stage need not belong to the biological group that gives the finest resolution of zones for that stage: these thin zones may be based on a group with limited geographical spread; may not normally be common; may be difficult to identify.

Once agreement has been reached on the defi- ning taxon, a boundary stratotype has to be selected. Surlyk (this volume) has listed the geological requirements, e.g. continuous sedimentation, no facies change across the boundary, high faunal diversity, no diagenesis, etc. These ideals would be frustrated without ease of access to the type locality; and it must be likely to survive as an exposure. After agreed selection such places containing the boundary-stratotype should be protected and preserved according to local custom, e.g. through purchase by the geological community, declared a national Nature Reserve.

\section{The base of the Cenomanian}

The principal problem of this boundary in ammonite terms is the status and existence in Tethyan areas such as Spain, north Africa, California, Texas, north Mexico, Brazil, Peru (?) and southern Japan of the Graysonites fauna above the highest mortoniceratids (i.e. typical Albian) and, in areas described to date, below the lowest Mantelliceras s.s. The stratigraphy of Graysonites zones in relation to other ammonites is still rather poorly known. In both Spain (Wiedmann \& Kauffmann 1978) and Brazil (Bengston 1983) the genus is said to be accompanied by Hypoturrilites but the divisions listed are clearly broad ones. The best detail is known from Texas (Young 1958a, b; Mancini 1979) where there are two zones, that of $G$. adkinsi below and $G$. lozoi above. Apart from additional species of Graysonites, the other ammonites in these zones are local species of Mariella (Wintonia) (= Plesioturrilites auct.), a subgenus that definitely straddles the Albian-Cenomanian boundary wherever it may be placed (see records in Kennedy \& Hancock 1977; Klinger \& Kennedy 1978). The absence of more cosmopolitan ammonite genera in these levels in Texas suggests some sort of ecological exclusion there, and supports the idea that the absence of the Graysonites assemblage in regions such as northern Europe may also be no more than ecological exclusion; that the Graysonites fauna is rigorously Tethyan.

Below the G. adkinsi Zone in Texas is a Zone of Mariella (Wintonia) brazoensis. The zone is placed above the highest mortoniceratids but the index species ranges downwards to overlap with mortoniceratids, e.g. Durnovarites and Drakeoceras (Young 1957). The absence of any hope of 
recognising this zone outside Texas would alone make it inadvisable to make it the basal zone of the Cenomanian; and an Albian dating is supported by planktic foraminifera: keeled rotaliporids are absent and hedbergellids predominate as in the Stoliczkaia dispar Zone at the top of the Albian in Switzerland (Renz et al. 1965; Mancini 1979). By placing the base of the Cenomanian in Texas at the base of the Zone of Graysonites adkinsi it would there be no more than $2 \mathrm{~m}$ below the appearance of keeled rotaliporid foraminifera such as Rotalipora evoluta Sigal (Mancini 1979).

Whilst we do not know if the Zones of Graysonites are represented in northern Europe by ammonite bearing beds, it will be better to choose a Tethyan succession for the standard. An obvious choice is to define the base of the Cenomanian by the base of the assemblage Zone of Hypoturrilites schneegansi. This is best known from the work of Dubourdieu (1956) in the borders of Algeria and Tunisia where it comprises some $200-250 \mathrm{~m}$ of clays. Dubourdieu divided his zone into three of which the bottom third (his Horizon A) was characterised by the appearance of Hypoturrilites, including $H$. schneegansi itself, Turrilites s.s. and Acompsoceras, but also contains Submantelliceras, Cottreauites and Prionocycloides(?). He reported three species of varieties as peculiar to this bottom subzone: Prionocycloides(?) zrissensis Pervinquière, Turrilites boukhadraensis Dubourdieu (a Mariella according to Klinger \& Kennedy 1978) and Idiohamites alternatus Mantell) var. rigida Sornay (=I. alternatus vectensis Spath). Nearly all these species are based on pyritic or limonitic internal moulds of nuclei of the ammonites. Some of them are the early growth stages of species known in northern Europe (and elsewhere) by later growth stages or adults, e.g. Mantelliceras martimpreyi (Coquand) an oft quoted north African form, is a synonym of Mantelliceras saxbii (Sharpe) (Kennedy \& Hancock 1971). The largest specimen of H. schneegansi figured by Dubourdieu is only 26 $\mathrm{mm}$ high and $16 \mathrm{~mm}$ wide. According to Dubourdieu the ornamentation recalls that of $H$. gravesianus but $H$. schneegansi has three times as many small tubercles as large tubercles, whilst $H$. gravesianus has only twice as many. $H$. schneegansi is reported as having 8 to 11 large tubercles per whorl, H. gravesianus 10 to 12
(Kennedy 1971), but this does not allow for a change in these numbers during ontogeny, for most described specimens of $H$. gravesianus are much larger. In fact it may well be $H$. betieri Dubourdieu that is a strict synonym of $H$. gravesianus.

During the symposium it was suggested that $H$. schneegansi was synonym of Neostlingoceras carcitanense (Matheron), the zonal index for the bottom zone of the Cenomanian in northern Europe. Although both have the same number of large tubercles, $N$. carcitanense has the flatter sides and higher whorls of Neostlingoceras, whereas $H$. schneegansi has the typically more squat appearance of true Hypoturrilites.

Whilst occasional Graysonites have been found in Tunisia (possibly Sharpeiceras laticlavium byzacenica Pervinquière, 1907, p. 312 , pl. 14, figs. $4 a-b)$, their stratigraphical position in the clay sequences with ammonite nuclei is unknown. The difficulty is that we do not know which 'Submantelliceras' nuclei represent Graysonites and which are other genera, such as Stoliczkaia. If Matsumoto (1960) was correct in his suspicion that Ammonites aumalensis Coquand is a Graysonites, then in Tunisia there may be Graysonites alongside mortoniceratids such as Durnovarites (Dubourdieu 1956, p. 267).

Hypoturrilites schneegansi has been recorded from the basal Cenomanian in Sarthe, France (Hancock 1960). Idiohamites alternatus (Mantell) including the variety vectensis Spath is one of the characteristic forms of the $N$. carcitanense Zone, the base of the Cenomanian of northern Europe.

\section{Possible boundary stratotypes}

Texas

If it is felt that the base of the Zone of Graysonites adkinsi should be used as the boundary, then it would lie low in the Grayson Marl, some $11 / 2 \mathrm{~m}$ above the top of the Main Street Limestone, but the lithology over the boundary is gradational. The total diversity of the Grayson fauna is considerable (fide Mancini) but there are no other stratigraphically useful macrofossils and the important keeled rotaliporids are scarce. The best known sections are at and near Grayson's Bluff, Denton County, some $35 \mathrm{~km}$ north-northeast of Fort Worth (Mancini 1977, 1979). The 


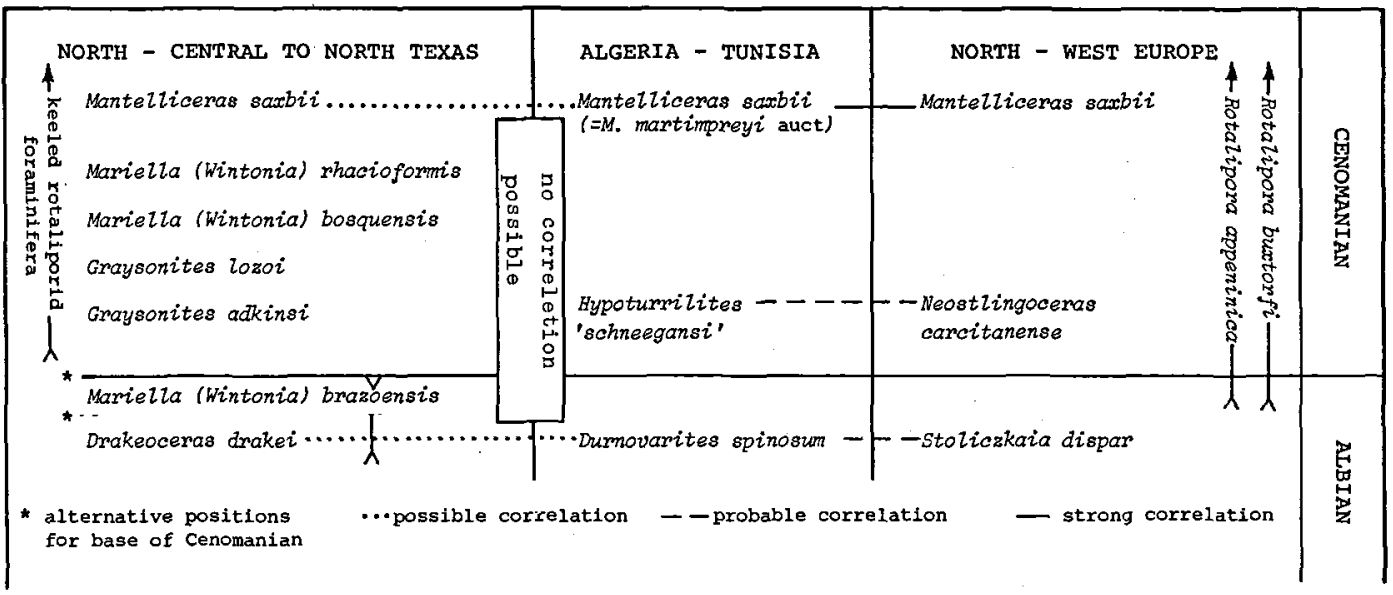

Fig. 1. Some ammonite horizons around the base of the Cenomanian and some related appearances of foraminifera. The Texan succession is based on Mancini, the north African succession on Dubourdieu and my own observations, the north-west European succession on Kennedy, Juignet, Robaszynski, Caron and myself.

exposures are partly natural lake cliffs, partly artificial excavations; the area is becoming progressively built over and would need protection. An alternative would be White Rock Creek, 6 km west of Aquilla, Hill County (Mancini 1977).

\section{Tunisia}

The best section is probably the natural exposure in the west flank of the north-south hill immediately north of $\mathrm{Hr}$. bou Rass $(009.3 ; 307.5) 4 \mathrm{~km}$ north of the northern slopes of Djebel Hameïa, about $50 \mathrm{~km}$ south-west of Le Kef, western Tunisia. The succession is an apparently continuous thick clay sequence with widely spaced thin marlstones in the southern part of the sillon tunisien (Castany 1953). Ammonites are the only macrofossils known from the beds anywhere close to the boundary, although a much more diverse fauna occurs in the neritic facies only a few tens of $\mathrm{km}$ to the south. The area is free from buildings and likely to remain so.

Much of the detailed work on the foraminifera succession in north Africa by Sigal (1952) was based on this region, but I know of no detailed bed by bed record from the Djebel Hameima area. In particular one would like to know the horizon of the appearance of Rotalipora (=Thalmanninella) brotzeni (Sigal) which according to Robaszynski \& Caron (1979) appears high in the Zone of Stoliczkaia dispar (i.e. in the highest Albian in the ammonite sense), but ac- cording to Salaj (1980) the appearance $R$. brotzeni (and hence the base of its Zone) lies above the base of the Cenomanian; the Zone of Rotundina stephani in the scheme of Salaj extends through the Stoliczkaia dispar Zone up into the basal Cenomanian.

Salaj $(1974,1980)$ has proposed the use of the sections at Djebel Fguira Salah, near Pont du Fahs in northern Tunisia as a Tethyan stratotype for the Cenomanian. At the base of Cenomanian he reports two laminated limestones with Sciponoceras baculoides (Mantell) and Mantelliceras aff. couloni (D'Orbigny); both these species indicate horizons well above the Zone of Hypoturrilites schneegansi and the Pont du Fahs region needs further investigation of its ammonite succession.

\section{The base of the Turonian}

Three horizons based on ammonites have been considered in recent years as a standard for the base of the Turonian.

1) At the base of the Zone of Metoicoceras geslinianum/Euomphaloceras septemseriatum. One or both of these species can be found in western Europe, central Europe, north Africa, Angola, Nigeria, western interior of the U.S.A., north and west Texas, California, Mexico, Co- 


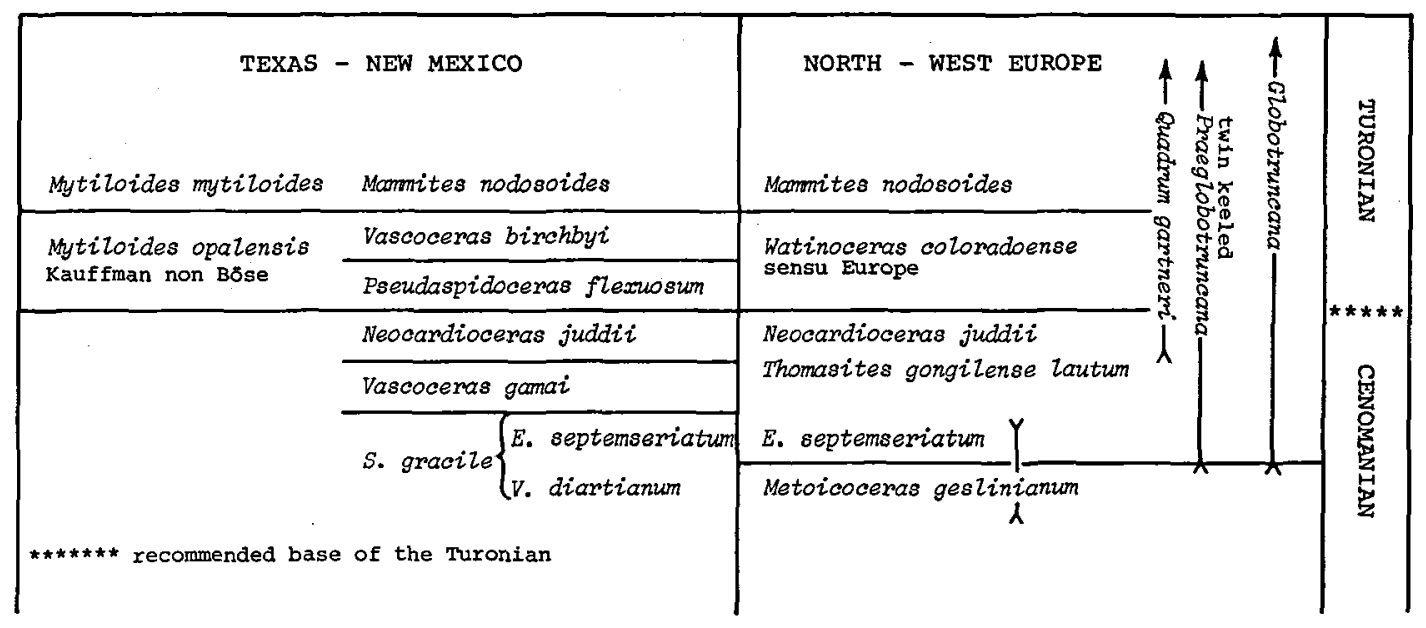

Fig. 2. Some ammonite horizons around the base of the Turonian and occurrences of other critical species. Based on speakers at the symposium and work done with Cobban, Kennedy and Wright.

lumbia, Brazil and Japan. Within this zone, i.e. a little above its base, lies the boundary between the foraminiferal Zone of Rotalipora cushmanil Praeglobotruncana stephani below and that of Globotruncana with twin keeled Praeglobotruncana above, which according to Carter \& Hart $(1977,54-55)$ is the most distinctive boundary in the Cretaceous System.

If this ammonite boundary is chosen a possible boundary-stratotype would be at Chispa Summit, north of Needle Peak, Jeff Davis County, Texas (40 km south of Van Horn, Culberson Country). The disadvantage of this section is that the foraminiferal fauna is abnormal (Frush \& Eicher 1975).

2) At the base of the Zone of Watinoceras coloradoense. The index species or closely allied ones are known from England, Czechoslovakia, Turkestan, the western interior of the U.S.A., and Canada; and possibly Angola, Cameroon and Morocco. This is the horizon most used by ammonite workers in recent years (e.g. Hancock, Kennedy \& Wright 1977; Wright and Kennedy 1981), but as Malcolm Hart remarked at the symposium, it is a horizon that is difficult for nonammonite workers to distinguish.

If this ammonite boundary is chosen a possible boundary-stratotype would be the Rock Canyon section, Pueblo County, Colorado (Cobban \& Scott 1972). Unluckily the foraminiferal fauna is again abnormal (Eicher 1969) but needs reinvestigation.

3) At the base of the Zone of Pseudaspidoceras flexuosum. The index species is at present known only from south-west Texas, northern Mexico and nearby, and Nigeria (W. A. Cobban pers. comm.) but will no doubt be found further afield now that attention is focused on it. Nevertheless, it seems to me a bad index species, because it has been recognised in so few places and belongs to a Tethyan genus with considerable nomenclatorial problems (see Wright \& Kennedy 1981). A better index would be based on a species of Vascoceras from this horizon.

Happily this horizon also coincides with the appearance of the main development of the $M y$ tiloides lineage as represented by $M$. opalensis Kaufmann non Böse (but above Mytiloides sp. aff. submytiloides (Seitz) sensu Kauffman) (see Kaufmann, Hattin \& Powell 1977). As E. Seibertz pointed out at the symposium, this inoceramid standard has the advantages of straddling the Tethyan-Boreal provinces, is relatively easy for the non-specialist to recognise, and the inoceramids are often common as well as being geographically widespread.

An obvious region for a boundary-stratotype is south-west Texas where the flexusosum Zone is best known and Mytiloides is common. Two possible localities are: (i) Chispa Summit, north of 
Needle Peak, Jeff Davis County, some $43 \mathrm{~km}$ south of Van Horn; (ii) an un-named limestone in the Ojinaga Formation, on the east side of Calvert Canyon some $300 \mathrm{~m}$ west of the small anticline in Buda Limestone, $3 \mathrm{~km}$ north-west of Love Triangulation Station in the Southern Quitman Mountains, Hudspeth County, some $42 \mathrm{~km}$ south-south-east of Sierra Blanca. Neither locality is likely to be built over. Calvert Canyon yields a better preserved and richer assemblage, including vascoceratids identified by Powell (1963) as Pachyvascoceras compressum and $P$. globosum Reyment, and which may include Vascoceras proprium Reyment, but is stratigraphically isolated with poorly fossiliferous shales immediately above and below. At both localities the foraminiferal fauna may be abnormal (Frush \& Eicher 1975).

Acknowledgements. The ideas in this paper owe much to the opposition of my friend C. W. Wright, and he has also helped me greatty in collecting the facts, as have W. A. Cobban and W. J. Kennedy.

\section{Dansk sammendrag}

Historiske definitioner af etager er ikke tilstrækkeligt præcise. Basis af cenomanien defineres bedst ved basis af Hypoturrilites schneegansi zonen med grænse stratotype nord for Djebel Hameina i Tunis. Den nedre cenomane Graysonites fauna kendt fra Tethys-området migrerede tilsyneladende ikke til boreale områder. Basis af turonien defineres bedst ved udviklingen af inoceramslægten $M y$ tiloides, i særdeleshed $\boldsymbol{M}$. opalensis Kauffman non Böse. Denne grænse svarer til basis af Pseudaspidoceras flexuosum ammonitzonen. Sydvest Texas er et velegnet område for en cenomanien-turonien granse stratotype; mest velegnet er formodentlig Calvert Canyon.

\section{References}

Carter, D. J. \& Hart, M. B. 1977: Aspects of mid-Cretaceous stratigraphical micropalaeontology. Bull. Brit. Mus. (Nat. Hist.), (Geol.) 29, 135 pp.

Castany, G. 1953: Notice explicative de la carte géologique de la Tunisie au 1/500,000. Tunis, S.E.F.A.N.

Cobban, W. A. \& Scott, G. R. 1972: Stratigraphy and ammonite fauna of the Graneros Shale and Greenhorn Limestone near Pueblo, Colorado. Prof. Pap. U.S. geol. Surv. $645,108 \mathrm{pp}$.

Dubourdieu, G. 1953: Ammonites nouvelles des Monts du Mellègue. Bull. Serv. Carte géol. Algér. Paléont. 16,76 pp.

Dubourdieu, G. 1956: Étude géologique de la région de l'Ouenza (confins algéro-tunisiens). Publs. Serv. Carte géol. Algér. Bull. 10,659 pp.

Eicher, D. L. 1969: Paleobathymetry of Cretaceous Greenhorn sea in eastern Colorado. Bull. Am. Ass. Petrol. Geol. 53, 1075-1090.
Frush, M. P. \& Eicher, D. L. 1975: Cenomanian and Turonian foraminifera and palaeenvironments in the Big Bend region of Texas and Mexico. Spec. Pap. geol. Ass. Canada 13, 277-301.

Hancock, J. M. 1960: Les ammonites du Cénomanien de la Sarthe. Compte- rendu Soc. sav., Dijon 1959: Colloque sur le Crétacé supérieur français 249-252. (mis-dated 1959).

Hancock, J. M., Kennedy, W. J. \& Wright, C. W. 1977: Towards a correlation of the Turonian sequences of Japan with those of north-west Europe. Spec. Pap. palaeont. Soc. Japan 21, 151-168.

Kauffman, E. G., Hattin, D. E. \& Powell, J. D. 1977: Stratigraphic, paleontologic, and paleoenvironmental analysis of the Upper Cretacoous rocks of Cimarron County, northwest Oklahoma. Mem. geol. Soc. Am. 149, 150 pp.

Kennedy, W, J. 1971: Cenomanian ammonites from southern England. Spec. Pap. Palaeont. 8, 272 pp.

Kennedy, W. J. \& Hancock, J. M. 1971: Mantelliceras saxbii, and the horizon of the Martimpreyi Zone in the Cenomanian of England. Palacontology 14, 437-454.

Kennedy, W. J. \& Hancock, J. M. 1977: Towards a correlation of the Cenomanian sequences of Japan with those of northwest Europe. Spec. Pap. palaeont. Soc. Japan 21, 127-141.

Klinger, H. C. \& Kennedy, W. J. 1978: Turrilitidae (Cretaceous Ammonoidea) from South Africa, with a discussion of the evolution and limits of the family. $\mathrm{Jl}$. moll. Stud. 44, 1-48.

Mancini, E. A. 1977: Depositional environment of the Grayson Formation (Upper Cretaceous) of Texas. Trans. Gulf Coast Ass. geol. Socs. 27, 334-351.

Mancini, E. A. 1979: Late Albian and Early Cenomanian Grayson ammonite biostratigraphy in north-central Texas. Jl. Paleont.53, 1013-1022.

Orbigny, A. d' 1852: Cours élémentaire de paléontologie et de géologie stratigraphiques. 2(2), 383-848.

Pervinquière, L. 1907: Études de paléontologie tunisienne. 1, Céphalopodes des terrains secondaires. Carte géologique de la Tunisie; Paris, Rudeval. 438 + v pp.

Powell, J. D. 1963: Cenomanian-Turonian (Cretaceous) ammonites from trans-Pecos Texas and northeastern Chihuahua, Mexico. Jl. Paleont. 37, 309-322.

Renz, O. Luterbacher, H. Reichel, M. Oertli, H. J. \& Stumm, F. 1965: Die mittlere Kreide von La Vraconne bei SteCroix (Kt. Waadt.). Bull. Verein. schweiz. Petrol. Geol. Ing. 31, 76-101.

Robaszynski, F. \& Caron, M. 1979: Atlas de foraminifères planctoniques du Crétacé moyen (mer boréale et téthys). Cahiers micropaléont. 1979, 1-185.

Salaj, J. 1973: Proposition pour des néostratotypes du Crétacé supérieur en vue de la zonation des régions de la Téthys. Annls. Mines Geol., Tunis 26, 219-222.

Salaj, J. 1980: Microbiostratigraphie du Crétacé et du Paléogene de la Tunisie septentrionale et orientale (hypostratotypes tunisiens). Bratislava, Institut geologique de Dionýz Ŝtúr. $238 \mathrm{pp}$.

Sigal, J. 1952: Aperçu stratigraphique sur la micropaléontologie du Crétacé. Int. geol. Cong. 19 (Alger), Monogr. rég. (1) Algérie $26,48 \mathrm{pp}$.

Sornay, J. 1957: Crétacé de France, Belgique, Pays-Bas, Luxembourg. Lexique Strat. Int. 1, fasc. 4 a vi, 403 pp.

Young, K. 1957: Upper Albian (Cretaceous) Ammonoidea from Texas. Jl. Paleont. 31, 1-33.

Young, K. 1958a: Graysonites, a Cretaceous ammonite in Texas. Jl. Paleont. 32, 171-182.

Young, K. 1958b: Cenomanian (Cretaceous) ammonites from Trans-Pecos Texas. Jl. Paleont. 32, 286-294.

Wright, C. W. \& Kennedy, W. J. 1981: The Ammonoidea of the Plenus Marls and the Middle Chalk. Monogr. Palaeontogr. Soc. $148 \mathrm{pp}$. 